Vol. 14, n² | 2010

Varia

\title{
Dreaming about the prison: Édouard Ducpétiaux and Prison Reform in Belgium (1830-1848)
}

Bert Vanhulle

\section{(2) OpenEdition}

Electronic version

URL: https://journals.openedition.org/chs/1196

DOI: $10.4000 /$ chs. 1196

ISSN: 1663-4837

Publisher

Librairie Droz

\section{Printed version}

Date of publication: 1 December 2010

Number of pages: 107-130

ISBN: 978-2-600-01470-0

ISSN: 1422-0857

\section{Electronic reference}

Bert Vanhulle, "Dreaming about the prison: Édouard Ducpétiaux and Prison Reform in Belgium

(1830-1848)", Crime, Histoire \& Sociétés / Crime, History \& Societies [Online], Vol. 14, n² | 2010, Online since 01 December 2013, connection on 23 March 2022. URL: http://journals.openedition.org/chs/ 1196 ; DOI: https://doi.org/10.4000/chs.1196 


\title{
Dreaming about the prison: Édouard Ducpétiaux and Prison Reform in Belgium (1830-1848)'
}

\author{
Bert Vanhulle ${ }^{2}$
}

\begin{abstract}
Les historiens du système carcéral se sont récemment intéressés à l'écart qui existe entre le discours pénitentiaire officiel émanant des spécialistes semi-officiels de la pénologie, et les pratiques pénales de la première moitié $d u X I X^{e}$ siècle. Il semble que les songeries théoriques des spécialistes $n$ 'interféraient guère avec les vieilles pratiques de la discipline carcérale. Dans cet article, j'attire l'attention sur Édouard Ducpétiaux, premier inspecteurgénéral du système pénitentiaire belge, qui fut reconnu comme un éminent théoricien et praticien de la justice pénale. Cet article vise à examiner si l'écart entre théorie et pratique évoqué est également visible dans les écrits et les actes de Ducpétiaux. Finalement, cet article s'interroge sur le point de savoir si le ferme soutien des théoriciens pénaux à l'emprisonnement cellulaire était dû au rejet des pratiques pénales (modernes) en vigueur.
\end{abstract}

Historians of the prison system have recently been interested in the discrepancy between the official prison discourse emanating from the semiofficial specialists of penology and prison practices during the first half of the nineteenth century. It seems that the theories of specialists did not have any significant impact on old practices of prison discipline. In this article I draw attention to Édouard Ducpétiaux, the first general-inspector of the Belgian prison system, who was recognised as a leading theorist as well as criminal justice practitioner. It is the aim of this article to investigate whether these discrepancies between theory and practice are also discernable in the writings and actions of Ducpétiaux. Finally, this article raises the question whether the strong support of the cellular regime among penal theorists was caused by the rejection of existing penal practices.

\section{LA SCIENCE PÉNITENTIAIRE BETWEEN THEORY AND PRACTICE}

$\mathrm{T}$ oday, the statement that the nineteenth century was a key period in the development of the modern prison system would hardly be contested. Since

I am indebted to the two anonymous reviewers who have made many insightful comments on an earlier version of this article.

2 Bert Vanhulle is currently a research assistant with the Université Catholique de Louvain (UCL). His research is part of the PAI 6/01-research-programme into the social and political history of Belgian criminal justice. He is currently finishing his Ph.D. on the Belgian prison science comptabilité morale at the KULeuven University, and has published in Dutch, English and French on different aspects of the history of the Belgian prison system. 
the publication of Michel Foucault's masterpiece Surveiller et punir in 1975 scores of historians and criminologists have described in detail the nineteenth century origins, rise and implementation of modern penitentiaries in almost every European country $^{3}$. One of the recurring themes addressed in these works is the position of national prison experts in the pan-European prison debate. This debate, which mainly took place in the 1830s and 1840s, helped to shape the image of the penitentiary as a decidedly modern element of penal policy. Regimes that saw themselves as modern and enlightened would therefore have no other option than to abolish the 'barbaric' spectacles of public corporal punishments, that were the hideous remnants of the Ancien Régime, according to enlightened jurists. In many countries this debate proved to be a strong incentive for local prison reform.

The issue that was so fiercely discussed by legal specialists, prison administrators, politicians and a growing network of prison specialists was the ideal prison system, especially following the publication of the rapport on the American prison systems by the French parliamentary observers, Gustave de Beaumont and Alexis de Tocqueville, in 1833. The penal specialists were united in their belief that there was a largely unexploited potential within European penal institutions for using incarceration as a tool for improving criminals. The introduction of a modern, improvement-oriented prison system became their common agenda. However, there was considerable disagreement among them about how this goal was to be achieved. The dispute between advocates of the cellular prison model and supporters of the communal model was particularly long-lasting ${ }^{4}$. A deluge of texts was published in the 1830 s and 1840s with projects for the much awaited prison reform, detailing the advantages that each model would have for the moral improvement of the prisoners. This was the ultimate and - according to those participating in this debate - perfectly achievable goal of each prison sentence, provided that the punishment was carried out in a modern penitentiary. This feverish enthusiasm for prison reform that gripped European intellectuals caused the French inspector-general of the prison system, Louis-Mathurin Moreau-Christophe, to observe in 1847, and not without irritation, that il semble qu'on ne puisse pas mourir sans faire accompagner son testament d'une petite brochure sur le système pénitentiaire ${ }^{5}$.

Moreau-Christophe was particularly targeting those who turned their attention to the prison system on the basis of vague philanthropic concerns. The future of the penal institutions had to be decided by people who had direct experience of them, i.e. the penologists. This attempt to defend their professional territory against 'philanthropic amateurs' was fairly typical of the struggle undertaken by the prison specialists in order to assert the identity of their science, known as science pénitentiaire, Gefängniskunde or simply penology. Whereas in the first decades of the nineteenth century the quest for prison reform was taken up by zealous religious philanthropists, inspired by the example of John Howard, the 'apostle of the prisons', a new group of prisons specialists emerged from the 1830s onwards. In their writings and correspondence about the ideal organisation of prison regimes, these specialists sought to distinguish themselves from the philanthropists by the use of modern

Foucault (1975). For an overview of this historiography see for instance Nutz (2001, pp. 1-12).

See for instance Riemer (2005, pp. 150-153).

Quotation taken from Roth (1981, p. 187). "It seems as if people cannot die without leaving a little leaflet about the penitentiary system as part of their will." 
objective sources of knowledge. The goal of their scientific reports was not merely to sanitise prison hygiene or denounce unacceptable treatment of inmates in local prisons, as they minimalised the activities and achievements of the philanthropists. The ultimate objective of the specialists' reports and debates was the reform of the entire prison system. This ambitious goal could only be reached if their belief in the reformatory power of modern penitentiaries became widely accepted. Crime statistics, inspection reports on existing practice and malpractice, as well as travel reports on the modern American prison system which prioritised prisoners' improvement were all used as arguments to strengthen their case.

The key-issue in this debate was the ideal prison system, but also other more mundane problems were discussed. Issues such as the preferred disciplinary regime within a penal institution or the need for penal law reform were also subjected to intense intellectual scrutiny. A definition of this 'science pénitentiaire' is not easy to provide. In the broadest terms, these penologists operated with the notion of detention and the closely associated question of the moral improvement of prison inmates. In the view of most specialists, their new science should be allowed to steer the process towards the expected improvement of the prison system ${ }^{6}$. By the time of the penitentiary congresses of 1846 and 1847, respectively held in Frankfurt and in Brussels, the debate about the ideal prison system was more or less settled in favour of cellular imprisonment. After the revolutions of 1848 this once flourishing panEuropean debate never returned with the same viguour ${ }^{7}$. The large interest in prison organisation had reached its climax and broader societal interest in the prison question quickly faded. As evidence of this decline is the fact the third penitentiary congress was organised as late as 1872 in London.

The furious, and even feverish, intellectual energy that was released in this panEuropean debate has primarily been interpreted as a sign of the allure of the 'promises of punishment', to paraphrase the title of Patricia O'Brien's well known work on the French prison system of the nineteenth century ${ }^{8}$. The technology of the modern prison would prevent criminals from straying from the right path by a mixture of deterrence, through strict discipline, and of moral and religious education appealing to the fundamental decency that was believed to be present in each criminal. The implementation of this modern prison ideology through legislation and prison institutions was a very slow process that steadily gained ground during the second half of the nineteenth century.

The historiographical focus on the international prison debate through the history of ideas has remained largely unchanged since the publication of Foucault's Surveiller et punir. Foucault analysed the international prison discourse of the first half of the nineteenth century as part of a new scientific language. In Foucault's view the 'invention' or the 'discovery' of the penitentiary must be seen as the origins of a new technology of disciplining which functioned as an instrument of power and social control for the ruling classes. The prison discourse and the debate on the ideal prison system obscured - and at the same time scientifically legitimised - this shift in disciplinary power. Later historians have not all adhered to Foucault's theories

\footnotetext{
6 Nutz (2005, pp. 431-459). See also Nutz (2001, pp. 259-260).

7 Riemer (2005, pp. 170-175).

8 O'Brien (1982).
} 
concerning the penitentiary, but the general appraisal of the importance of the panEuropean debate stayed firmly rooted within the history of ideas.

According to the canon of prison historiography, the existence of the prison debate of the 1830s and 1840s points to a growing interest and subsequent acceptance in wider society of the reformative ideal of the penitentiary. Supporters of incarceration formed a more or less coherent front of specialists who believed in the possibility of criminals' moral improvement by means of modern penitentiary technologies. They organised and campaigned successfully for prison building and legal reform. The idea of the penitentiary thus emerged from the prison debate and gradually became acceptable to the wider public. Institutional changes were preceded by this campaign of awareness. Prison historians have not questioned this united frontthesis which was first advocated by Foucault. They have constructed a historical narrative of gradual realisation of the idea of the reformative prison through prison regimes, penal legislation and government policy. According to the historiographical canon, these reformative ideas were central in steering the development of the prison system through much of the nineteenth century. Only from the 1870s onwards did this societal consensus concerning the role and possibilities of the penitentiary come under severe attack by criminal anthropologists and neo-classical jurists. Although the implementation of this modern penal thought at the institutional level has been described thoroughly by a younger generation of historians in the 1980s and 1990s, there is still a lot of ground left to cover.

For instance, only the overall themes and some main figures of the panEuropean prison debate have been presented in scientific research. The French historian Jacques-Guy Petit has admirably reconstructed the marginalisation of the philanthropic thought in France by the protagonists of the science pénitentiaire ${ }^{9}$. Other elements that have not been taken into account include the inner workings of the network of prison supporters, a thorough analysis of its participants, its hierarchical structures, and the circulation of knowledge within this network. It is equally unclear how much these new penitentiary ideas influenced existing penal practices. Building plans, prison regimes and reports from prison officials have been extensively studied. Similarly, analyses of parliamentary debates and the introduction of new legislation have been duly researched; yet, still the question remains how exactly this new reformative ideology was integrated in prison practice. Historians who describe the institutional rise of the penitentiary generally discuss new model penal institutions that were created by prison enthusiasts, but rarely investigate the shift in existing practices. Seán McConville's work on the English prison administration is a notable exception to this lack of attention to penal practice, but his work in turn lacks a broader analysis of the influence of European intellectual debates on prisons ${ }^{10}$.

Recent German research has tried to add this two-sided 'practical' dimension in the history of the evolution of the prison system. A notable work was written by the German scholar Thomas Nutz, who was the first to analyse the networks and strategies of legitimisation employed by the prison specialists ${ }^{11}$. Lars Hendrik Riemer's publication of the letters by the nineteenth century German prison specialist Karl

\footnotetext{
9 Petit (1990, pp. 198-205). See also Petit (1982, pp. 333-336).

10 McConville (1981).

11 Nutz (2001).
} 
Josef Anton Mittermaier has proven to be an invaluable source in unearthing the workings of the European prison network. Riemer has also provided this edition with a very interesting introduction to the topics that were discussed in the network and the hierarchical structure of what he calls the Netzwerk der Gefängnisfreunde ${ }^{12}$. Furthermore these two scholars have presented in-depth analyses in two separate articles; Riemer on the composition and hierarchy within the prison network and Nutz on the problematic implementation of the modern prison thought.

The latter has drawn attention to the conflict of interests between local bureaucrats and scientific authorities during the reform of the Prussian prison system, notably in the case of Nikolaus Heinrich Julius ${ }^{13}$. During the 1830s and 1840s, Julius, who had been intensively involved with the prison reform movement since 1828 , had been able to strengthen his position from an academic with some influence in his own country to a penologist of international reputation ${ }^{14}$. Julius played an important role in the pan-European network of penologists, which came into being in the 1830s. 'Dr. Julius', as he was commonly referred to, became one of the bestknown German advocates of a modern prison system constructed according to scientific penological principles. In the debate about the 'communal model' versus the 'cellular model', Julius opted resolutely for the latter. It was for this reason that he was designated by King Frederick William IV of Prussia in 1840 to steer prison reform in his country ${ }^{15}$. Nutz shows convincingly in his article that the existing prison administration was displeased with the interference from Julius as 'specialist'. The prison officials as a whole were not convinced that Julius' claims about the merits of the cell-based prison were justified. After 1848, Julius was completely sidelined by the administration, despite recurrent pressure from the monarch to make use of Julius' services. Julius' scientific knowledge was opposed, and ultimately successfully ignored during the implementation of prison reform in Prussia.

A contribution by Riemer to a collection of essays about prison specialists discusses the relationship between leading penologists who considered prison reform from a 'scientific' perspective and the prison governors (the Praktiker from the title of his article) who approached the penitentiary question from a more pragmatic and empirical angle ${ }^{16}$. The difference of approach and the enormous discrepancy in their prestige made for a troubled relationship between the two groups. Although Gefängniskunde was essentially centred on prison practice as a discipline, it were nevertheless academics and senior officials who engaged in the debates despite having little or no sense of what prison life was really like. This was partly due to the low prestige of local prison officials - including the prison management. Often, though not always, they lacked the education and ambition to make their voices heard in the prison reform debate. Secondly, it was due to the specific direction that the prison debate took in the 1830s and 1840s, when the search for a universally applicable organisational system for prisons came to dominate the science pénitentiaire. This debate was not conducted one the basis of the experience of individual prisons. Protagonists from both camps argued the merits of their preferred system

\footnotetext{
12 Riemer (2005).

13 Nutz (2005, pp. 452-457).

14 Nutz, (2005, p. 440).

15 Nutz (2005, p. 453).

16 Riemer (2007, pp. 35-53).
} 
through a combination of theoretical and practical arguments. General ideas about the origin of criminality and depravity and about the merits of solitude and control of prisoners as a group were used as arguments to support any particular prison system. The experiences of prison governors were only cited by the penologists if they fitted with their reasoning. Not surprisingly, some prison governors tried to make their voices heard in this debate, which - throughout the period from the mid-1830s until the penological congresses of 1846 and 1847 - was mainly conducted via correspondence, monographs and journal articles. They sought to find a middle way between the two 'main systems', however, their proposals were passed over by the 'Fürsten der Wissenschaft'. According to the prison specialists it was not clear whether measures which worked well in one specific institution were in fact universally applicable. According to the penologists the observations made 'from below' were often too closely related to the personality of the governor or reflected the composition of the prison population to be universally applicable. The penologists ambition to construct an universally applicable and scientific theory of the ideal prison system thus stifled the voice of the practitioners.

To my knowledge Reimer and Nutz's articles are the first to explore the inner workings of the prison network from an organisational point of view. Nutz's article hints at a hidden level in the implementation of prison reform, one that has been glossed over by historians who describe the rise of the penitentiary mainly as a mental discursive shift. It can be concluded from the analyses of Riemer and Nutz that despite the rapid growth of penology in the 1830s and 1840s, the actual influence of its scientific insights on existing prison practice remained limited. Both authors point to the awkward relationship between the theoretical discursive level of prison reform and the practical level of prison life as a possible explanation. Both describe the prison specialists as alien to prison practices. Their views could thus easily be ignored by the practitioners. This article is not based to the same degree on this antagonistic model. It focuses on the activities of the Belgian penologist Édouard Ducpétiaux.

Édouard Ducpétiaux was appointed inspector-general of the Belgian prison system in 1830, only a few months after the successful Belgian revolution. This appointment took place shortly after his $26^{\text {th }}$ birthday; his superior in the Belgian prison administration, Charles-François Soudain de Niederwerth, was his senior by two years. These two young intellectuals were assigned the task of organising the Belgian national prison system according to the most modern insights. Unlike Julius, Ducpétiaux was thus from the beginning an integral element of the prison administration. At the same time, Ducpétiaux built up his position during the 1830s and 1840 s to become an internationally respected penologist. In 1846 he would convene the first penal congress together with Mittermaier, Julius, Moreau-Christophe and other acclaimed penal specialists ${ }^{17}$. In other words, the theory and practice of the prison reform movement was united in the single figure of Ducpétiaux. Was there any interaction between theory and practice in Ducpétiaux's activities and publications or was the discrepancy that Nutz and Riemer identify also present in his case? Can an analysis of Ducpétiaux's activities explain why the international Gefängniskunde opted for the cellular regime?

17 Débats Francfort-sur-le-Main (1847, p. 3). 
Ducpétiaux's background was mainly in journalism and law. In the 1820s he had built up something of a reputation in the then southern provinces of the United Kingdom of the Netherlands. He had fiercely opposed the death penalty in various polemical writings. Ducpétiaux's first publication, at the age of 23, was De la peine de mort (1827). In this work, which he published before completing his legal studies, he vehemently denied the supposed value of the death penalty. He used the Latin translation of one chapter from this work, $d u$ châtiment propre à remplacer la peine de mort as his university dissertation in the same year ${ }^{18}$. Ducpétiaux argued that the alternative to capital punishment was a prison system centred on the improvement of the prisoner. His views reflected the abolitionist debate which was also in full swing in France, where Charles Lucas also proposed an improvement-oriented prison as the most effective substitute for capital punishment ${ }^{19}$.

The expertise that Ducpétiaux had built up through this and other writings on related topics was mainly focused on the 'ideal prison'. However, the question of how this ideal prison should be organised in practice remained unanswered in these abolitionist works. By 1831, at the time of his entry into the prison system, Ducpétiaux's thinking seems to be mainly theoretical.Yet, Ducpétiaux himself stressed his first-hand experience of the existing prison system. During the reign of the Dutch king William I, Ducpétiaux's liberal pen had put him on the wrong side of the law at several occasions. He was also locked up by the Dutch authorities during the Belgian uprising. The shocking experiences of the way in which prisons were organised convinced Ducpétiaux of the urgent need for prison reform. After the Belgian independence, his former revolutionary comrades gave him the opportunity to help shaping government policies in this field.

This, at least, is the romanticised story that Ducpétiaux himself was particularly proud of. A rather hagiographical biography, written in the 1920s only reinforced this vision ${ }^{20}$. Since no personal archive has been preserved, Ducpétiaux's writings and a few archival data are the only available inroads to study him. As a result Ducpétiaux has largely succeeded in creating his own legend. In his final text, a sort of penitentiary testament, he looked back on his achievements as inspector of the Belgian prison system. He particularly praised the introduction of the cellular regime in the Belgian prison system as his personal struggle and his main achievement $^{21}$. Ducpétiaux's (self)image as some sort of Prometheus for the cellular system has continued in Belgian historiography ${ }^{22}$. Although Marie-Sylvie Dupont-Bouchat should be credited for drawing attention to Ducpétiaux's fascination with French utopian social reformers like Saint-Simon and Victor Considérant, she has also strengthened the image of Ducpétiaux as an isolated supporter of the cellular model $^{23}$. In this article I would like to look beyond this carefully constructed image and beyond the analysis of his work within the framework of the history of ideas. I believe that analysing Ducpétiaux's views on prison reform as that of a practitioner

\footnotetext{
18 Ducpétiaux (1827).

19 Lucas (1827). For an interesting analysis of the abolitionist debate and its links with prison reform in Belgium see De Brouwer (2009).

20 Rubbens (1922).

21 Ducpétiaux (1865).

22 Dupont-Bouchat (1988).

23 Dupont-Bouchat (1988, p. 7). For Ducpétiaux’ ties with Considerant see Beecher (2001).
} 
can contribute to a better understanding of his preference for the cellular model. It is a myth, created by Ducpétiaux himself, that the cellular system was already at the centre of his prison ideology in the 1830s. Furthermore I intend to analyse Ducpétiaux's dealings with the penal floor, a topic that has been largely ignored in international as well as in Belgian prison historiography.

In the first part of this article I discuss Ducpétiaux's theoretical writings and his steady climb within the international network of prison specialists. In the second part I research his early achievements in Belgian prison reform before 1848. I consider 1848 as a turning point in the history of the Belgian prison system. In 1848 the principle of individual imprisonment was adopted into Belgian penal law, culminating in the law on penal imprisonment of 1870 which stated that every prison sentence should be carried out in cellular confinement ${ }^{24}$. The tacit parliamentary agreement of 1848 to the cellular system led in Belgium to an ambitious building programme of cellular prisons from the 1850 s onwards. A third reason to see a turning point in 1848 was the decline of the international prison debate in the years after 1848 , caused by the political upheaval that many European countries had witnessed.

\section{DUCPÉTIAUX AND THE THEORY OF PENOLOGY: HIS ENGAGEMENT WITH THE PAN-EUROPEAN DEBATE AND THE PREFERENCE FOR THE CELLULAR SYSTEM}

Little is known of Ducpétiaux's activities during the first few years after the Belgian independence in 1830. His first inspection visit - the conduct of such visits being one of his core tasks under the decree confirming his appointment - was made to the prisons of Ghent and took place on 9 January $1833^{25}$. During the first two years after his appointment, the new inspector-general apparently made several trips to different prisons around Europe, probably in order to widen his practical knowledge of daily prison life and organisation. In a number of letters that have been preserved, Ducpétiaux depicts a deplorable picture of the provincial prisons that he visited on his journey through Alsace ${ }^{26}$. This was the first of many visits to foreign institutions, an activity that other penologists also engaged in during these years as a way to broaden their knowledge. In a letter to the editors of the French journal Annales d'hygiène publique et de médecine légale dated late December 1832, Ducpétiaux refers to visits to penal institutions in France, Switzerland and Germany ${ }^{27}$. In 1835 he also visited the British Isles ${ }^{28}$.

Through these visits, Ducpétiaux sought to gain information about the organisation of foreign prisons, thus adding to his own practical knowledge of prison life. He alluded to this in his contribution to the Annales d'hygiène publique et de médecine légale. Ducpétiaux argued that most intellectual efforts had so far focused on developing the theoretical principles of penology without paying any attention to practi-

24 Maes (2006).

25 State Archive depot Beveren (RABeveren), Archive of the prisons of Ghent (SI Ghent), inventory number 5, Notes of the meeting of the administrative commission 9 January 1833.

26 Strijpens (1992). See also Vercruysse (1999).

27 Ducpétiaux (1833a, p. 273).

28 Riemer (2005, p. 1080). 
cal issues: il y a cent ouvrages qui traitent de l'amélioration des prisons, je n'en connais pas deux qui envisagent la question sous le point de vue de l'utilité pratique; les théories sont nombreuses et les moyens de les appliquer peu connus ${ }^{29}$. Ducpétiaux was thus urging theorists to pay more attention to prison practices and administration.

The foreign trips and prison visits that Ducpétiaux undertook during this period also served a second goal, though. He was building up a network of correspondents who would keep him informed about developments of prison policies in foreign countries. This form of networking has been referred to rather dismissively by some historians as le tourisme pénitentiaire. Yet this practice was one of the most common ways of exchanging knowledge about existing prison systems right up until the $1840 \mathrm{~s}^{30}$ In 1834, Ducpétiaux replied to a letter from the German jurist and prison reformer Karl Josef Anton Mittermaier ${ }^{31}$. It was the beginning of a correspondence between Ducpétiaux and Mittermaier that would continue for almost thirty years ${ }^{32}$ Through Mittermaier Ducpétiaux was introduced to the pan-European prison network in which jurists, penologists and government officials were active. The participants in this informal network kept each other informed about local prison news through letters, reciprocal visits and the dissemination of official and semi-official reports ${ }^{33}$. The prison experts found crime statistics, official as well as unofficial, particularly attractive. Rates of recidivism and crime figures were used to develop arguments about the effectiveness of particular measures taken or the need for reform. Monographs were also exchanged in which local legislation and the transformation of prisons to penitentiaries were central topics.

In the early years Ducpétiaux's role within this network was limited to providing statistics and information about Belgian crime rates and prison policies. In the first letters between Mittermaier and Ducpétiaux, it is clear that the Belgian inspectorgeneral was in a subordinate position. For example, he expressed explicitly his thanks to Mittermaier for documents the latter had sent. For his part, Ducpétiaux sought to entice the German jurist with proposals for articles for the journal edited by Mittermaier, Kritische Zeitschrift für Rechtswissenschaft und Gesetzgebung des Auslandes $^{34}$. Ducpétiaux can be regarded in this phase as a criminal justice practitioner who provided the theorists with useful data. This is clear from a letter from Mittermaier to Julius from 1836: Ich freue mich dass Du mit Ducpétiaux Bemühungen zufrieden bist. Er ist ein geistvoller Mensch - im letzten Hefte meiner Zeitschrift ist ein ziemlich guter Aufsatz über Criminalstatistik von Belgien ${ }^{35}$.

29 Ducpétiaux (1833a, p. 295). "There are at least one hundred books dealing with the question of improving prisons. I have not come across two that consider the question in terms of how ideas might be carried out in practice. The theories are numerous, but little is known about how to apply them." Dupont-Bouchat (2002, pp. 533-563).

31 The first letter from Ducpétiaux to Mittermaier dates from 15 august 1834, see Riemer (2005, p. 1078).

32 The last letter from Ducpétiaux to Mittermaier dates from 1862, see Riemer (2005, pp. 1106-1109).

33 Nutz (2001, pp. 282-306).

34 Riemer (2005, p. 1081).

35 Riemer (2005, p. 531). "I am pleased that you are satisfied with the efforts made by Ducpétiaux. He is an enthusiastic young man - in the last volume of my review you will find a rather good analysis of Belgian criminal statistics." 
Ducpétiaux's role and importance within the international prison network was extended after the publication of his Des progrès et de l'état actuel de la réforme pénitentiaire in $1838^{36}$. The work's subtitle, Appendice [...] à l'ouvrage de MM. G. de Beaumont et A. de Tocqueville sur le système pénitentiaire aux États-Unis makes it clear that through this monograph Ducpétiaux was seeking to make a contribution to the European debate on the ideal prison system. In the first two volumes, he discussed prison organisation and reform in the United States, France, Switzerland and the United Kingdom as well as provided a detailed analysis of the Belgian situation. He also dealt extensively with the question of the ideal form of prison organisation, coming out clearly in favour of cellular confinement (confinement solitaire).

The strongest argument in favour of the cellular regime, according to Ducpétiaux, was that it made it absolutely impossible for prisoners to communicate with one-another. As a result, inmates would no longer be able to influence each other. In this contemplative cell life, only the beneficial influence of constant work, education and regular consoling contacts with moral agents (the chaplain, the instructor and the governor) would be possible ${ }^{37}$. After the introduction of the cellular regime, the prisons would no longer be 'schools of vice' (écoles de vice), but true 'schools of repentence' (écoles de repentir). Among other things any pernicious influence from lower-ranking prison officials was reduced in this system. Separate confinement facilitated the prisoners' contacts with higher officials such as the chief warden, governor, chaplain, doctor or instructor. These would be able to set a far more positive example for the prisoners and were more likely to bring about the desired moral regeneration: leur éducation, leur expérience, leurs lumières, rendent assurément plus aptes à étudier les caractères, à sonder les cours des condamnés, et par suite à approprier les remèdes aux maux dont ils auront constaté l'existence ${ }^{38}$.

To illustrate his point, Ducpétiaux, in the third volume of the work, drew upon a number of examples of prison practices from the renowned Ghent prison $\mathrm{He}$ included the full report of the prison doctor Daniel-Joseph Mareska about health conditions in the Ghent prisons which was provided with additional commentaries. The accounts of homosexuality in prisons were particularly shocking and challenging to contemporaries. Mareska apologised for providing what he called 'obscene details', but took the view that such abuses should not be passed over in silence ${ }^{39}$. This was grist to Ducpétiaux's mill. The communal system that was applied in Ghent's prisons in accordance with the strictest standards could neither prevent nor eradicate such 'unnatural acts'. Salvation for the prisoner and the prison system in general could only be developed in the cellular regime.

Ducpétiaux's reputation was transformed by this work, turning him into one of Europe's leading penologists. Belgian reviews of his work were generally favourable and few challenged his position as a penal specialist. Ducpétiaux's

\footnotetext{
36 Ducpétiaux (1838).

37 Ducpétiaux (1838, vol. 2, p. 229).

38 Ducpétiaux (1838, vol. 2, p. 232). "With their education, their experience and their levels of insight, they are undoubtedly in the best position to assess the personalities of the inmates, to look into their hearts, and subsequently to judge by which means the evil that they have identified might be rectified".

39 Ducpétiaux (1838, vol. 3, pp. 323-326).
} 
credentials as a penal reformer certainly were enhanced with this publication and his position within the Belgian prison administration was suitably strengthened. In his initial contacts with Mittermaier, Ducpétiaux remained modest about the book. After its publication he sent a copy to Mittermaier and described it as a project that had gotten out of hand. He explained that originally he had only intended to provide a compilation of recent studies on the penal question to accompany a new edition of the work of de Tocqueville and de Beaumont. Due to the wealth of material, he then decided to issue an independent work ${ }^{40}$. Ducpétiaux was downplaying the importance of his work. For the first time, he was taking a clear and well-founded standpoint on the question of the ideal prison system. This discussion would become the most important topic for the penological research over the following decade. Ducpétiaux justified his preference for the cellular regime on the basis of his 'modest' experience as inspector-general: J'y ai pris parti pour le système d'emprisonnement séparé; c'est que ma conviction et le peu d'expérience que j'ai acquise dans l'exercice de mes fonctions, m'y poussaient d'une façon en quelque sorte irrésistible ${ }^{41}$. He was again stressing his links with prison practice, no longer from the position of former prisoner, but in his capacity as a senior official within the prison administration.

Strengthened by this publication, Ducpétiaux ventured for the first time into a debate with Mittermaier. The eminent German scholar was a convinced champion of the Swiss communal system, in which inmates worked together in silence during the day and were locked up in cells at night ${ }^{42}$. Ducpétiaux admitted that the system had its merits, but doubted the effectiveness of this method of imprisonment in principle, since it allowed prisoners to keep company with one another ${ }^{43}$. In subsequent years, the two men would develop from colleagues to friends, despite the enduring difference of opinion about the ideal prison regime.

In what the Belgian criminologist Eric Maes has labeled his magnum opus, Ducpétiaux reiterated his support for the cellular regime in the Mémoire à l'appui du projet de loi sur les prisons. He wrote this work in 1845 in order to help ensure the passing of a new law by the Belgian Parliament that introduced the cellular regime as the standard for all Belgian prisons ${ }^{44}$. On the basis of a dazzling array of tables, statistics and arguments Ducpétiaux concluded that the cellular system was incontestably superior to the communal system, whether in its European or its American variant. Remarkably, out of the book's 300 pages, only around fifty dealt with Belgian prisons. Furthermore, only two pages referred to Belgian prison governors (Riemer's Praktiker), all of whom concluded that the communal confinement of prisoners was failing to achieve the desired moral improvement ${ }^{45}$. They expressed

40 Riemer (2005, p. 1084).

41 Riemer (2005, p. 1084). "I have opted for the system of cellular imprisonment; it is my personal conviction, and whatever limited experience I have acquired in my capacity as prison inspector forces me to draw this conclusion as inevitable."

42 Riemer (2005, pp. 190-200).

43 Je désire que la théorie que vous défendez avec un si noble et beau talent, porte des fruits salutaires, bien que j'en doute un peu. Quotation from Riemer (2005, p. 1084). "I wish that the theories that you defend with such high-minded and excellent talent will bear healthy fruits, although I have my doubts."

44 Maes (2009, p. 53). For a comprehensive analysis of the parliamentary discussion concerning the introduction of the cellular system in Belgium see Maes (2009, pp. 663-684). See also Weber (1996).

45 Ducpétiaux (1845, p. 43). 
their views in writing at the request of Ducpétiaux, who had invited every prison governor to set out his views about the shortcomings of the existing system.

Ducéptiaux's reputation as a penologist was officially confirmed when in 1846 he was asked to help organising the first penal congress in Frankfurt. The programme of this conference primarily concerned the question which of the two prison systems was preferable. No fewer than fifteen of the twenty-two questions, on which the participants of the conference were to deliberate, related to aspects of the different prison systems ${ }^{46}$. Ultimately, only eight resolutions would be taken at the Frankfurt congress, due to the extensive debates ${ }^{47}$. Separate confinement was accepted by a large majority as the preferred form of punishment, both for suspects and for those condemned to short or long prison sentences ${ }^{48}$. In his various interventions at the congress, Ducpétiaux particularly emphasised 'l'élasticité $d u$ régime cellulaire $^{, 49}$. Individual imprisonment could be made more or less severe and adapted to individuals in many different ways, whereas the communal punishment lacked this flexibility ${ }^{50}$. Strikingly, Ducpétiaux did not make one single reference to his activities as inspector-general in providing this appraisal. During the debates at this congress, his support for separate confinement was based on theoretical considerations of the merits stemming from this method of imprisonment.

In the following congress in Brussels in 1847, attention was mainly focused on the architectural application of the penal principles established in Frankfurt. A second question concerned the issue whether the cellular regime should be extended to young offenders. In the discussions at this congress it became clear how difficult it was to determine generally applicable principles. The role that religious congregations should play in the prison regime proved to be a particularly controversial point $^{51}$. For Ducpétiaux, his position as general secretary at the Brussels penal conference constituted a high point in his career and confirmed his status as a leading figure in penology. As a theorist he had opted early on for the cellular system and found himself thus in the 'winning' camp. Yet, to what extent did Ducpétiaux succeed in getting these ideas introduced in Belgian prison practice?

\section{DUCPÉTIAUX AND THE PRISON FLOOR: THEORY INTO PRACTICE?}

As inspector-general of the Belgian prisons, Ducpétiaux conducted a policy that was based on his theoretical positions. Only lack of funds prevented him from organising the Belgian prisons entirely in line with the cellular model that he propagated at the international forum. New constructions of small detention centres and local correctional institutions were in line with cellular principles, although there was no legislative basis for doing so. The first of these institutions was the cellular prison of Tongeren built in 1844 . By that time, the legislation initiated by the then Minister of Justice, Jules d'Anethan, to make cellular imprisonment official policy

\footnotetext{
46 Débats Francfort-sur-le-Main (1847, pp. 4-5).

47 Débats Francfort-sur-le-Main (1847, pp. 160-161).

48 Débats Francfort-sur-le-Main (1847, p. 102).

49 Débats Francfort-sur-le-Main (1847, p. 123).

50 Débats Francfort-sur-le-Main (1847, pp. 123-124).

51 Débats Bruxelles (1847, pp. 152-176).
} 
had not yet been debated in the legislative chambers, despite the support of Ducpétiaux $^{52}$. Without legislative endorsement of the cellular regime, it was virtually impossible to fund the conversion of the existing large prisons from communal to cellular institutions.

To relieve the burden of the large prison institutions, Ducpétiaux had hitherto pursued a policy of diversification. Different groups among the prison populations who had previously been confined in the same location were now moved into new accommodations. A women's prison was founded in Namur in 1837, while from 1840 onwards young offenders were sent to a converted monastery at St. Hubert ${ }^{53}$. Ducpétiaux also insisted that convicted prisoners should not come into contact with people held on suspicion or those imprisoned for debt. The separation of the various groups of inmates according to age, gender and nature of conviction was intended to reduce the disorder that was rampant in the large prisons. This was to facilitate more effective inculcation of moral principles into prisoners

In the large correctional and penal institutions, Ducpétiaux organised the overall population into smaller groups in an attempt to limit the harmful influence of the communal regime. The classification criteria for these groups were strictly determined. The inmates were not only to be classed by age, gender or crime. Their degree of depravity could also serve as a guideline for determining the unit in which they were to be placed. These rather defensive measures were intended to impede mutual corruption. However, the plans for improving prisoners were also carried out in a more positive manner. Religious instruction by the chaplain was combined with ordinary education, so that the prisoners would leave the penal institutions with a certain level of educational achievement ${ }^{54}$. Vocational training was another area that was taken very seriously in prisons. In 1835 Ducpétiaux attempted to set up a patronage system that would support released prisoners ${ }^{55}$.

In theory at least, the Belgian prisons were moving towards becoming total institutions supposedly transforming people through modern technologies of punishment and re-education. The broad outlines of the policy in this period can thus be regarded as translating Ducpétiaux's views into the existing national frameworks, although within existing financial and infrastructural constraints. However, a closer look at prison practices shows that not everything that Ducpétiaux prescribed was actually taken up without further questions.

The modernisation of the prison infrastructure seems to have been a priority in the first decade following Belgian independence. Such efforts cannot be distinguished from the new goals of prison reform. The desired moral improvement of prisoners was only achievable when given suitable physical conditions: lorsque les locaux seront convénablement appropriés à cet effet wrote Ducpétiaux in $1833^{56}$. In a letter to the administrative committee of the prisons of Ghent, Ducpétiaux explained the changes he would like to see implemented following his inspection

\footnotetext{
52 Maes (2006, p. 16).

53 'Arrêté royal instituant une maison centrale de détention pour les femmes condamnées de toutes les catégories', ministère de la Justice (1840, p. 76). See also Dupont-Bouchat, Alexandre and Strimelle (1996).

54 See for instance 'Règlement pour l'école de la maison de détention de Vilvorde (28 décembre 1831)', ministère de la Justice (1840, pp. 99-101).

55 'Rapport au roi sur le patronage des condamnés libérés, et arrêté royal à ce sujet', ministère de la Justice (1840, pp. 160-162).

56 Ducpétiaux (1833b, p. 23). “...once the space has been appropriately converted for this purpose.”
} 
visit. The majority of his points can be described as improvements to the standards of hygiene and enhanced security measures. Among other things, Ducpétiaux called for improvements to the infrastructure such as paving the inner courtyard, relocating the latrines and installing extra safety fences or doors. One final point related to the reorientation of the purpose of imprisonment, which Ducpétiaux had articulated for the first time in the decree containing the rules for obtaining a royal remission for prisoners: he expressed the wish to hold newly arrived prisoners in "moral quarantine' before they came into contact with other prisoners ${ }^{57}$. After this quarantine period, a decision could be made as to which group the prisoner were to belong. The insights into the prisoner's mind and into the extent of his moral depravity that had been gained during the 'moral quarantine' would help the prison staff to form a reasonably comprehensive judgement of the prisoner before his entry into prison: ce serait de cette époque que devraient dater les premières notes sur leur caractère ${ }^{58}$. The members of the committee recorded in their minutes of the meeting that on doublera des soins à cet égard ${ }^{59}$.

Other comments were less favourably received by the committee members. One point of disagreement was the request from the central administration that only women who were under correctional detention should be accommodated in Ghent prison. The administrative committee was not opposed to the philosophy underlying this proposal, namely the grouping together of prisoners who had incurred the same type of sentence ${ }^{60}$, but they expressed their opposition to the set system of distribution. The members of the Ghent prison board believed they had the right to take care of female prisoners convicted to long sentences under the criminal law given that it was more lucrative to accommodate this type of prisoner ${ }^{61}$. This group had been allocated to the prison in Vilvoorde. The income that was expected from women convicted to these long sentences was higher than that for women submitted to correctional sentences. Their shorter sentences meant that comparatively more time had to be devoted to teaching work techniques to the prisoners. Another point of conflict was the proposal to install artificial lighting so that the inmates could also work in the evenings. This was repeatedly rejected by the committee members ${ }^{62}$. According to Ducpétiaux, working in artificial light could serve as a puissant moyen de réformation ${ }^{63}$, but in their reply the committee members mainly referred to the safety risks associated with such an undertaking ${ }^{64}$.

57 RABeveren, SI Ghent 5, Notes of the meeting of the administrative commission 18 April 1832.

58 Ducpétiaux (1833b, p. 40). "It should be from this period that we collect the first observations on the character of the prisoner."

59 RABeveren, SI Ghent 5, Notes of the meeting of the administrative commission 18 April 1832. "...we will reinforce the efforts on this point."

60 "Arrêté concernant la classification des femmes condamnées et des détenus enfants et adolescents (9 November 1832), ministère de la Justice (1840, p. 118). See also Dupont-Bouchat (1995, pp. 23-53).

${ }_{61}$ RABeveren, SI Ghent 5, Notes from the meeting of the administrative commission 3 October 1832.

62 RABeveren, SI Ghent 5, Notes from the meeting of the administrative commission 12 December 1832. See also RABeveren, SI Ghent 6, Notes from the meeting of the administrative commission 4 February 1835 and 23 December 1835.

63 Ducpétiaux (1833b, p. 28). “... a powerful means of moral regeneration.”

64 RABeveren, SI Ghent 5, Notes from the meeting of the administrative commission 12 December 1832: 'could bring about great disorders and provoke the immorality we have almost eradicated'.'devant amener des grands désordres et provoquer l'immoralité qu'on est presque parvenu à extirper.' 
The committee members further contested both Ducpétiaux's proposals and those of the prison administration concerning other matters. Their protests became particularly vehement when substantive interventions were planned from the central administration which went further than adjustment to material or infrastructure. They were not convinced of the merits of reorienting imprisonment towards moral improvement. For example, the introduction of a cellular regime for part of the prison population was met with incomprehension on the part of the Ghent committee members. They were not convinced of the benefits of this new-fangled idea, and had it recorded that their views were based sur l'expérience de près de cinq années qui [...] a donné l'intime conviction que le système actuel (communal confinement) laisse peu de choses à désirer ${ }^{65}$. Somewhat sarcastically they added that l'administrateur supérieur décidera dans sa sagesse lequel des deux systèmes doit être préférét 6 .

The order given by Soudain de Niederwerth to keep out visitors who would only visit the establishment for the sake of une stérile curiosite was also dismissed as irrelevant ${ }^{67}$. The members of the administrative committee responded to this in no uncertain terms: La maison de force est placée au nombre des établissements les plus curieux de la Belgique; en exclure les personnes qui ne pourraient prouver $q u$ 'elles y vont dans les vues exprimées par l'administration, serait en quelque sorte en exclure tout le monde, d'ailleurs il arrive fréquemment que des étrangers s'arrêtent pendant une journée à Gand pour voir ce bel établissement. Les en priver serait agir contrairement à ce qui toujours a existé ${ }^{68}$.

The irritation expressed by members of the administrative committee with the meddling from the central administration became more pronounced as time passed. The modern ideas developed by the two youths, Ducpétiaux and Soudain de Niederwerth, were rejected with the argument that it was better to leave things as they were. The experience of the committee members was certainly preferable to the youthful arrogance of these two high-ranking officials. However, much to their irritation, the members of the administrative committee were repeatedly forced to climb down on these points. They felt their influence weakening to the advantage of central authority. Furthermore, the central administration considerably reduced the strength of the committee by introducing a system whereby a third of the committee's members came up for re-election every other year ${ }^{69}$. According to Ducpétiaux, this was simply an attempt to involve as many honest citizens as possible in this

65 RABeveren, SI Ghent 5, Notes from the meeting of the administrative commission 28 May 1834. " $\ldots$ on the experience of almost five years, which had led to the firm conviction that the present system (the communal regime) leaves little to be desired."

66 RABeveren, SI Ghent 5, Notes from the meeting of the administrative commission 28 May 1834. " ... the senior administrator will decide in his infinite wisdom which of the two systems is preferable."

67 RABeveren, SI Ghent 5, Notes from the meeting of the administrative commission 20 August 1834.

68 RABeveren, SI Ghent 5, Notes from the meeting of the administrative commission 20 August 1834. "The prison is amongst the most curious establishments in Belgium. To exclude anyone who cannot prove that he visits while in full agreement with the expressed views of the prison administration would be to exclude everybody. By the way, it frequently happens that foreigners stay for one day in Ghent simply to see this beautiful establishment. To deprive visitors from this experience would be to act contrary to practices which have always existed."

69 'Arrêté relatif au renouvellement des commissions administratives (1 ${ }^{\text {er }}$ novembre 1832)', in Ministère (1840, p. 117). 
œuvre de bienfaisance et de dévouement ${ }^{70}$. Irrespective of the justification, it effectively weakened the local committees.

Ducpétiaux was conscious of the hostility which remained among the local prison staff and management. In his first report from 1833 to the Belgian parliament about the state of the national prisons he implicitly criticised the prison staff. The current prison officers, he claimed, were incapable of changing from performing purely disciplinary functions to become the desired agents of moral regeneration: Mais ces premiers essais tentés dans l'intérêt de la réformation des détenus, pour réussir, nécessitaient le concours d'employés capables et dignes à tous égards de travailler à l'œuvre importante préparée par l'administration ${ }^{71}$. Only the members of staff with the required abilities would be retained, and the rest would be discarded and replaced ${ }^{72}$. The first steps towards this were taken in 1837 with the introduction of nuns from a religious order to run the women's section of Ghent prison ${ }^{73}$. For the male prisoners, the Brothers of Our Lady of Charity, better known as the Brothers of Scheppers after their founder Victor Scheppers, were brought in ${ }^{74}$. The use of these Brothers in the prison system was a relatively inexpensive way of employing prison staff with some level of education. Initially, the Brothers were asked to take on a variety of specific tasks such as the care of sick inmates, but in the course of the 1840 s and 1850s they were assigned to other functions. These included the role as wardens of the cell blocks or responsibilities for the instruction of prisoners ${ }^{75}$.

One might argue that the prison policy operated by Ducpétiaux consisted of the gradual introduction of the cellular model in smaller prisons. The first cell-based prison was brought into use in Tongeren in 1844. In prisons where this was not possible, an alternative system of strict classification was preferred. A variety of new institutions were built to accommodate specific subgroups. Work, education and religious instruction were used to bring about the desired moral improvement of the inmates. The central administration restricted the freedom of action of the local administrative committees by appointing members for a short period only. The negative influence of ill-educated prison wardens was diminished by employing members of male and female religious orders as part of the workforce. Ducpétiaux's penal programme seems to have been fully achieved in the $1840 \mathrm{~s}$, apart from the complete introduction of the cellular regime.

In contrast to the experience of Dr. Julius in Prussia, Ducpétiaux succeeded, at least in part, in introducing the cellular prison organisation. In Belgian prisons, the discrepancy between theory and practice as identified by Nutz and Riemer apparently did not apply. As a criminal justice practitioner who made the leap to become

70 Ducpétiaux (1833b, p. 9). “... in acts of charity and devotion.”

71 Ducpétiaux (1833b, p. 9). "But these first tentative attempts towards the moral regeneration of prisoners depended for their success on cooperation from staff who were, in all respects, capable and worthy of working towards the higher goals set by the prison administration."

72 L'épuration et le renouvellement successif d'une partie du personnel des prisons... Quotation from Ducpétiaux (1833b, p. 9).

73 RABeveren, SI Ghent 6, Notes from the meeting of the administrative commission 4 January 1837.

74 Mechlinien (1982).

75 Correspondance 'Scheppers' in the private archive of the Brothers of Scheppers, Mechelen. Letter dated 6 July 1844 from Scheppers to the Belgian Minister of Justice. See also letter dated 6 January 1848 from Scheppers to Baron de Hody or letter dated 10 May 1855 from Scheppers to the Minister of Justice. 
a leading theorist, Ducpétiaux, unlike other colleagues, actually managed to successfully apply his insights into prison policy, albeit not without resistance from local prison committees. The main obstacle for Ducpétiaux's penitentiary ambitions seemed to be the uncooperative attitude of members of parliament who were reluctant to officially endorse the cellular model. Supported by his position as an internationally renowned penologist, he tried to influence decision-makers by publishing the aforementioned work, Mémoire à l'appui du projet de loi sur les prisons. His reputation was certainly enhanced by his stellar climb within the international prison network.

Ducpétiaux condemned rather harshly the existing Belgian prison system in the Mémoire. Although being himself a leading prison official, he described Belgian prisons as primitive and completely failing in achieving their goal: on ne peut méconnaître l'action funeste de la captivité, l'affaiblissement du principe de l'intimidation, l'insuffisance des moyens d'amendement, l'absence du repentir ${ }^{76}$. This bitter and severe appraisal is all the more surprising in view of the more optimistic tone of earlier works and reports, which had emphasised and praised the progress of the Belgian penal system. Ducpétiaux's tough line can probably be explained by the specific context of the publication. In 1840, the inspector-general had had to admit defeat in the debate about the implementation of youth prisons. Against his will, the government had allocated an old monastery in St. Hubert as the only institution for young offenders. Ducpétiaux had always pleaded for at least three special borstals ${ }^{77}$. Ducpétiaux wanted to stand his ground this time using the official legitimation of his cellular approach. This explains in part the book's tone.

Yet the structure of Ducpétiaux's argument is revealing for his growing distance from prison practice. Whereas Ducpétiaux in earlier works and reports made ample use of empirical examples from daily prison life, these are completely absent from the Mémoire. Ducpétiaux prefered to illustrate his claims by describing the Belgian situation in statistics, as was customary in the international science pénitentiaire. The statistics on recidivism were particularly important to him. As these were on the increase Ducpétiaux saw this as a telltale sign that should not be ignored by policy-makers ${ }^{78}$. In terms of the perceived problems in the penitentiary system, Ducpétiaux did not approach the discussion from the viewpoint of everyday prison life. Only the 'objective' statistical data that attempted to capture that reality mattered to him. The same man, who in 1832 had been pleading for more attention paid to the practical aspects of the prison system, completely ignored penal practices in his book of 1840 .

However, there was a seamy side to the Belgian prison system, which was home to more suffering and gruesome stories than Ducpétiaux's figures could capture. For example, the members of the administrative committee of the Ghent prisons showed considerable skill in hushing up scandals. In 1839, an officiating chaplain was sidelined after being suspected of having published a rather unflattering article in a local newspaper about the use of corporal punishments in Ghent prisons. This mistreat-

\footnotetext{
76 Ducpétiaux (1845, p. 45) "one cannot ignore the negative effects of imprisonment, the undermining of the principle of deterrence, the inadequacy of the means of improvement and the absence of repentance."

77 Maes (2009, p. 242).

78 Ducpétiaux (1845, pp. 44-45).
} 
ment had led to the suicide of a prisoner ${ }^{79}$. Worse still, in a sermon the chaplain had urged the prisoners not to subject to such abuses any longer. Through intervention by the bishop of Ghent, the problem was dealt with and the clergyman was pensioned off ${ }^{80}$. During the same year, a female prisoner claimed to have been raped by an unknown man in the courtyard of the women's prison. She admitted this six months later when she was no longer able to conceal her pregnancy. She was pardoned with a reduced sentence to buy off her silence ${ }^{81}$. In neither case did the central administration get involved.

The international prison discourse, using terms such as improvement, moral regeneration and repentance, sounds rather hollow in the face of such incidents. Ducpétiaux's modernisation project did not seem to take very firm roots in everyday prison life. It is striking that the administrative committee of Ghent still had enough power to settle these affairs amicably. The interests of the local administrative committee members and of the central administration also clashed on other matters. For instance, the introduction of the Brothers of Scheppers did not go without opposition. At the military prison of Alost, the local chaplain conducted a bitter campaign of vilification against the Brothers, supported by the members of the administrative committee $^{82}$. These incidents impeded the creation of the desired moral education intended to set the prisoners on the right path. Victor Scheppers, founder and superior of the Brotherhood, complained in a letter to Alexis-Guillaume de Hody, successor of Soudain de Niederwerth as director of the prison system, that it was not the prisoners but the governors who were the greatest opponents of his Brothers ${ }^{\prime 83}$.

Nor did the prisoners themselves turn out to be particularly impressed by the new regulations. In 1835 a work trading racket among the prisoners was exposed. Ducpétiaux and Soudain, who both regarded work as a pillar of the reformatory project, were shocked to discover how prisoners handled this 'privilege'. Those who were condemned to hard labour for life would sell the proceeds of their work to prisoners with a limited sentence. Thus the work of the 'lifers' was handed over to the other prisoners in exchange for extra food or snacks from the canteen and smuggled goods. As the inmates received a piece wage, this fraud was relatively easy, and could sometimes even be organised $a d h^{84} c^{84}$. This system was organised by those condemned to hard labour for life because the prison system had failed to devise a system for the treatment of their wages that was appropriate to their specific situation. As was the case with the other prisoners, most of their wages were put aside as a savings allowance (masgeld), which was normally only paid out at the time of a prisoner's release. According to the rules of this system, they could only have free use of a limited amount of pocket money, whereas their savings would continue to accrue until their death. After their death, the saved money would be paid out to their

79 Tweegesprek (1839): "these prisoners [...] who were there so severely beaten from a warden ..."; "Is that their way to moralise those poor devils ..."

80 RABeveren, SI Ghent 6, Notes of the meeting of the administrative commission 17 July 1839.

81 RABeveren, SI Ghent 6, Notes of the meeting of the administrative commission 30 November 1839 and 18 December 1839.

82 Mechlinien (1982, p. 135).

83 Private archive Brothers of Scheppers, Letter dated 22 November 1845 from Scheppers to de Hody: les directeurs, qui en général sont les adversaires des frères ...

84 SI Ghent 6, Notes of the meeting of the administrative commission 25 November 1835. 
heirs or would revert to the prison. The prisoners' racket had obviously been operating for a few years before it was discovered. The committee members were astounded to discover that prisoners who had already been working for several years in Ghent central prison did not have a cent of savings.

Such incidents show that the regime of improvement that Ducpétiaux aimed for was only introduced very partially, although the official policies were based on the most modern penal principles. Not only did the administrative committees turn out to be not nearly as toothless as had been thought, but the new regulations also went wide off the mark on more than one occasion. The dichotomy between theory and practice thus turns out also to have characterised Belgian prisons, despite Ducpétiaux's advantageous position as an ideal link between the two aspects. Although being an eminent figure among international scholars of penology, the impact of his decisions on the life of the Belgian prisoner turns out to have been relatively limited. Incidents such as the beatings and the rape in Ghent demonstrate that the decried immorality that prevailed in the prison institutions of earlier periods was still present in Belgian prisons after their modernisation. Ducpétiaux's success proved very insecure.

In several rapports from the Ghent prison, increasing criticism was heaped on Ducpétiaux's programme of cellular prison reform. It is striking that in these rapports Ducpétiaux was clearly considered an outsider, someone who built his penal expertise on theoretical sandcastles without having a proper practice-based knowledge of crime or criminals. In 1836 this dismissal is still carefully worded. The creation of a cellular wing in Ghent prison was a but louable according to the local prison director, but he did not believe it would bring the intended amélioration morale. Criminals were, according to this prison official, too firmly entrenched in a life of vice for a mere prison sentence to make much of an impression on them ${ }^{85}$. More than local inertia and the desire to leave things unchanged, the opposition in Ghent prison to the reform proposals from Ducpétiaux and the central administration stemmed from a fundamentally different attitude to criminals and scepticism about the potential for moral regeneration of prisoners. No matter how refined the techniques were, a complete moral improvement seemed very unlikely to local prison officials. This distrust in the reformative goal of the prison sentence was based on their day-to-day dealings with the prisoners, who proved time and time again to be immune to moral administrations.

In a report of 1848 detailing the activities of the Brothers of Scheppers, the Ghent prison doctor Daniel-Joseph Mareska all but buried the reformative ideal of prison sentences: Lorsque la constitution physique de l'homme est mauvaise, la médecine parvient rarement à la changer; il en est de même pour le moral, lorsqu'il est profondément corrompu la religion et la philosophie restent le plus souvent impuissantes. C'est une triste pensée, mais pourtant elle est vraie. In the same vein he stated that one should not flatter oneself with grand ideas of creating moral improvement, but be content if one succeeded in purifying the moral atmosphere of a prison. That was according to Mareska the only realistic goal of the modern prison system ${ }^{86}$.

85 RABeveren, Provincial Archive of East-Flanders 2438/6, Notes on twoweekly meeting of main prison staff Ghent prison 29 January 1836, attached to a letter from the governor of East-Flanders to the administrateur-général des prisons, 1 February 1836.

86 RABeveren, Provincial Archive of East-Flanders 2361/6, Rapport on Brothers of Scheppers from Jean Mareska to governor of East-Flanders, 22 January 1848. "When a man's physical constitution 
In a general report of 1849 on the physical and moral effects of prison sentences, that was circulated in print in 1852, Mareska stated, in no uncertain terms, the complete failure of improvement-based cellular prison system: Nous avons vu fonctionner pendant des années le système d'isolement [...] il nous en coûte d'en faire l'aveu, mais nous en sommes à nous demander si nous avons produit le moindre bien ${ }^{87}$. He added dejectedly: À ceux qui nous objecteront que nous n'avons pas toujours tenu un pareil langage, nous répondrons: nous parlions autrefois le langage de la théorie, nous parlons aujourd'hui celui de l'observation et de l'expérience ${ }^{88}$.

\section{CONCLUSION: DREAMING ABOUT THE PRISON}

Edouard Ducpétiaux's views underwent an interesting development during the period under consideration. From being an outspoken criminal justice practitioner with relatively little interest in the theoretical approach to prison reform, he evolved to become a leading theorist. This development was mainly caused by his integration in the pan-European network of prison specialists. At the international level, his transformation was extremely successful. Ducpétiaux's international prestige was acknowledged by Belgian members of parliament who lauded his scientific credentials as well-deserved ${ }^{89}$. Although before 1848 the Belgian parliament was reluctant to give their full support to Ducpétiaux's endeavours to promote the cellular system, their reservations were quickly discarded in the 1850s. Ducpétiaux's international reputation, combined with relatively minor unrest in Belgium in 1848, led to the adoption of cellular-based prison reform as official policy. An ambitious building programme realised Ducpétiaux's ambitions to introduce the cellular system. From the 1850s onwards, the Belgian prison system became almost synonymous with the cellular regime. Thus, in the long run, Ducpétiaux's international strategy proved to be successful.

In order to make the transition from prison practitioner to prison theorist, Ducpétiaux had to adopt a different tone and alter the argument of his published works. Ducpétiaux's works in the early 1830s were focused on the spreading of practical knowledge of prisoners' living conditions. Over the years, he became increasingly preoccupied by a more theoretical approach to the prison issue. Ducpétiaux successfully emulated the international penological discourse and devoted less and less space to the discussion of the Belgian situation in particular. That his interest in prison practices was replaced by a more theoretical framework of reference is strikingly illustrated by the contents and lines of argument in the Mémoire. The conflict between theory and practice, as described by Riemer, also characterised the

is poor no medicine is likely to change that ; the same goes for the moral constitution: when it is profoundly corrupted, religion and philosophy are most often impotent. It is a sad thought, but a true one."

87 Mareska (1852, p. 39). "For years we have seen the system of individual imprisonment in practice (...) It is hard to admit it, but we must ask ourselves if we have done the slightest good."

88 Mareska (1852, p. 40). "To those who will object that we have not always spoken in these terms, we will reply: then we were speaking the language of theory; today we speak from observation and experience."

89 See the quotation of Belgian liberal member of parliament Adelson Castiau in Maes (2009, p. 682). 
writings and actions of Ducpétiaux, although the inspector-general himself continued to stress his ties with the practical functioning of prison administration.

Although Belgian prison policies clearly bore the mark of Ducpétiaux's thinking, it remains to be seen how great his influence was on the practices within the prison system. Neither the prisoners nor the local prison administrators seemed enthusiastic about the proposed reorientation towards an improvement-based prison system. Local inertia can explain the early reluctance to fully embrace the penal thoughts advocated by the young prison administrators Ducpétiaux and Soudain de Niederwerth during the first decade of Belgian independence. From the 1840s onwards a fundamentally different assessment of the value and goals of the prison system was made by those running the prisons. Their belief in the potential for the moral regeneration of inmates was rapidly fading, a development caused by years of practical experience and repeated failures. The opposition from the prison practitioners towards Ducpétiaux's penitentiary project became more vocal over the course of the 1840s. Ducpétiaux himself was regarded by the prison practitioners as a theoretician, who remained naïvely unaware of prison reality. It is remarkable that it was precisely during this period that Ducpétiaux's views on the merits of the cellular regime became rigid and more theoretically-based.

It can be assumed that this strained relationship with prison practitioners was an important factor in Ducpétiaux's turn towards theory and his option for the radical cellular system. A close reading of the theoretical reflections that the leading lights of the science pénitentiaire formulated in their publications of the 1840s reveals a hankering for a different type of prison institution. Perhaps this is why the choice in favour of the cellular regime was made so clearly in international prison discourse. Safety was scarcely an issue in the cellular prison; there was no need for crowd control for the prisoners and the prisoners would be exposed to modern improvement techniques under the most auspicious circumstances, without having to be concerned about failings on the part of prison guards or local administrators. Over time, the ideal image of a prison which was kept alive on the basis of this discipline lost all touch with actual practices. And perhaps that was precisely the point.

This discrepancy between theory and practice would be exposed in the final quarter of the nineteenth century. A radical rethinking of the function and purpose of prison institutions was propagated during this period against the background of new thinking in disciplines such as the neo-classical criminal law philosophy (the défense sociale-doctrine) and criminal anthropology. The insights of the classical science pénitentiaire were systematically discarded. It is noticeable how explicitly these new disciplines in the field of penology related their scientific claims to empirical evidence. Cesare Lombroso gained his knowledge from the bodies of the prisoners, Alexandre Lacassagne rigorously noted the biographical accounts of prisoners and their social milieux, while Belgian défense sociale advocate Adolphe Prins pointed to the abstract human image of classical law in general and the science pénitentiaire in particular.

The example of the Belgian prison system strikingly illustrates the powerlessness of international penology in its heyday. This interpretation radically differs from conclusions presented in the main canon of prison historiography. The prison discourse of the 1830s and 1840s did not point to the existence of a united prison front whereby, minor disagreements aside, everyone adhered to more or less the same view. Apart from the discourses by certain prison specialists, there was a reality that is seldom studied and in which prison practitioners had to re-evaluate their 
own beliefs about the potential for moral regeneration of the criminal. Men like Daniel-Joseph Mareska started their career in the prison service fully enthralled by the idea of the possibilities of the modern penitentiary. After twenty years in prison service Mareska was forced to conclude that the initial aims of the penitentiary were unachievable and that it was necessary to set more realistic and less ambitious goals. While leading penologists like Ducpétiaux continued to believe in the ability to morally improve prison inmates and saw this as a key quality of the cellular system, a mental shift away from the original aims of punishment had already taken place among prison practitioners.

Analyses that approach the writings, activities and prison policy of Ducpétiaux from the perspective of the history of ideas give a superficial view of prison reality. If focusing exclusively on these aspects, one could easily construct a narrative of successful and logical implementation of the cellular system into Belgian prison policies. However, an analysis of the reactions of the prison practitioners to these new prison policies shows that this image is distorted. Even a universally renowned penologist like Ducpétiaux was unable to put his insights into the science pénitentiaire fully into practice. The prison policies he pursued, with emphasis on the education and reform of prisoners, did not live up to his high expectations. The universal support for the cellular approach within the international network of penologists can be seen as a final attempt to redeem the improvement-principle which was fundamental to the success of the penitentiaries. In essence, the choice of the cellular regime represented a rejection of existing practice and the pursuit of a utopian project. By the mid-1840s, the discrepancy between prison theory and modern penal practice had become impossible to reconcile. The science of the prison system ultimately became confined to mere dreams about the ideal prison.

Bert Vanhulle

Research Assistant PAI 6/01 - UCLouvain Centre d'Histoire du Droit et de la Justice (CHDJ)

Rue du Poirier 10

B - 1348 Louvain-la-Neuve Bert.Vanhulle@uclouvain.be

\section{ARCHIVAL SOURCES}

State Archive depot Beveren (RABeveren), Archive of the prisons of Ghent, Notes of the meeting of the administrative commission 1830-1848 (inventory numbers 1-7); Provincial Archive of East-Flanders, 1830-1850.

Correspondance Scheppers, in the private archive of the Brothers of Scheppers, conserved Mechelen, the Belgian see of the Brothers of Scheppers.

\section{REFERENCES}

Anon, Tweegesprek: historie van Amman, De Vaderlander, 1838, 1, p. 65.

Anon, Débats du congrès pénitentiaire de Francfort-sur-le-Main, 28, 28 et 30 septembre 1846, Paris, E. Marc-Aurel, 1847a. 
Anon, Débats du congrès pénitentiaire de Bruxelles, session de 1847. Séances de 20, 21, 22 et 23 septembre, Brussels, Deltombe, 1847b.

Anon, Mechlinien. beatificationis et canonizationis Servi Dei Victoris Scheppers, sacerdotis, fundatoris Institutum Fratrum B.M.V. a Misericordia, 1802-1877: positio super virtutibus ex officio concinnata, Rome, 1882.

Beecher, J., Victor Considerant and the rise and fall of French romanticism, Berkeley, University of California Press, 2001.

De Brouwer, J., 'Un peuple civilisé n'use du dernier supplice qu'avec répugnance...' La peine de mort en Belgique au XIX $X^{e}$ siècle, Louvain-la-Neuve, unpublished doctoral thesis, 2009.

Ducpétiaux, É., Dissertatio inauguralis juridica de poena poena capitali substituenda, Ghent, unpublished dissertation, 1827.

Ducpétiaux, É., Questions relatives à l'hygiène des prisons et des établissements de bienfaisance, Annales d'hygiène publique et de médecine légale, 1833a, 1, 9, pp. 272-295.

Ducpétiaux, É., Rapport sur l'état actuel des prisons en Belgique, sur les améliorations qui y ont été introduites depuis la révolution et sur la nécessité de l'introduction du système pénitentiaire, Brussels, $1833 \mathrm{~b}$.

Ducpétiaux, É., Des progrès et de l'état actuel de la réforme pénitentiaire et des institutions préventives aux États-Unis, en France, en Suisse, en Angleterre et en Belgique. Appendice général aux ouvrages les plus récents sur la réforme des prisons, et particulièrement à l'ouvrage de MM. G. De Beaumont et A. De Tocqueville sur le système pénitentiaire aux États-Unis, Brussels, Société belge de librairie, 1838.

Ducpétiaux, É., Mémoire à l'appui du projet de loi sur les prisons, présenté à la chambre de représentants de Belgique dans la séance du 3 décembre 1844, avec un appendice et trois plans de prisons cellulaires, Brussels, Weissenbruch, 1845.

Ducpétiaux, É., Réforme des prisons. Système cellulaire, Brussels, Comptoir universel d'imprimerie et de librairie, 1865.

Dupont-Bouchat, M.-S., Ducpétiaux ou le rêve cellulaire, Déviance et Société, 1988, 12, 1, pp. 1-27.

Dupont-Bouchat, M.-S., De la prison à l'école de bienfaisance. Origines et transformations des institutions pénitentiaires pour enfants en Belgique au XIX ${ }^{\mathrm{e}}$ siècle (1840-1914), Criminologie, 1995, 28, 1, pp. 23-53.

Dupont-Bouchat, M.-S., Du tourisme pénitentiaire à l' «Internationale des philantropes ». La création d'un réseau pour la protection de l'enfance à travers les congrès internationaux (1840-1914), Paedagogica historica, 2002, 38, 2-3, pp. 533-563.

Dupont-Bouchat, M.-S., Alexandre, F., Strimelle, V., De la prison à l'école. Les pénitenciers pour enfants en Belgique au XIX'e siècle (1840-1914), Kortrijk, UGA, 1996.

Foucault, M., Surveiller et punir. Naissance de la prison, Paris, Gallimard, 1975.

Lucas, C., Du système pénal et du système répressif en général, de la peine de mort en particulier, Paris, Béchet, 1827.

Maes, E., De individuele cellulaire opsluiting tussen instrumentalisering en rechtsbescherming. De wet van 4 maart 1870 in confrontatie met de 'Basiswet... van 12 januari 2005', Belgisch tijdschrift voor nieuwste geschiedenis, 2006, 36, 1, pp. 7-48.

Maes, E., Van gevangenisstraf naar vrijheidsstraf. 200 jaar Belgisch gevangeniswezen, Antwerp, Maklu, 2009.

Mareska, D.J., Étude des effets de l'emprisonnement sur les condamnés criminels en Belgique (rapport annuel de 1849), Brussels, Lelong, 1852.

McConville, S., A history of English prison administration, 1750-1877, London, Routledge, 1981. 
Ministère de la Justice, Recueil des arrêtés, règlements et circulaires concernant les prisons de Belgique, Brussels, Société typographique belge, 1840.

Nutz, T., Strafanstalt als Besserungsmaschine. Reformdiskurs und Gefängnis-wissenschaft, 1775-1848, München, Oldenbourg Wissenschaftsverlag, 2001.

Nutz, T., Global networks and local prison reforms: monarchs, bureaucrats and penological experts in early nineteenth-century Prussia, German History, 2005, 23, 4, pp. 431-459.

O'Brien, P., The promise of punishment: prisons in nineteenth century France, Princeton, Princeton University Press, 1982.

Petit, J.-G., L'amendement ou l'entreprise de réforme morale des prisonniers en France au XIX ${ }^{\mathrm{e}}$ siècle, Déviance et Société, 1982, 6, 4, pp. 331-351.

Petit, J.-G., Ces peines obscures. La prison pénale en France, 1780-1795, Paris, Fayard, 1990.

Riemer, L.H. (ed.), Das Netzwerk der 'Gefângnisfreunde’ (1830-1872). Karl Josef Anton Mittermaiers Briefwechsel mit europäischen Strafvollzugsexperten, Frankfurt am Main, Klostermann, 2005.

Riemer, L.H., 'Fürsten der Wissenschaft' und 'arme kleine Praktiker'? Theoretiker und leitende Strafanstaltsbeamte im Gefängnisreformdiskurs des 19. Jahrhunderts, in Schauz, D., Freitag, S. (Eds), Verbrecher im Visier der Experten. Kriminalpolitik zwischen Wissenschaft und Praxis in 19. und frühen 20. Jahrhundert, Stuttgart, Steiner, 2007, pp. 3553.

Roth, R., Pratiques pénitentiaires et théorie sociale: l'exemple de la prison de Genève (18251862), Geneva, Droz, 1981.

Rubbens, E., Édouard Ducpétiaux, 1804-1868, Brussels, Dewit, 1922.

Strijpens, H., Édouard Ducpétiaux’ reis Brussel-Straatsburg anno 1832 en het ontstaan van de Europese beweging, Aalst, Excelsior, 1992.

Vercruysse, T., Édouard Ducpétiaux (1804-1868) als penitentiair hervormer: de centrale gevangenis in Leuven (1860) als realisatie, Leuven, unpublished dissertation, 1999.

Weber, D., Homo criminalis. Belgische parlementsleden over misdaad en strafrecht, 18301940, Brussels, VUB press, 1996. 